\title{
PENGARUH QUALITY OF WORK LIFE (QWL) DAN ORGANIZATIONAL COMMITMENT (OC) TERHADAP ORGANIZATIONAL CITIZENSHIP BEHAVIOR (OCB) PADA PERAWAT TETAP
}

\author{
EFFECTS OF QUALITY OF WORK LIFE (QWL) AND ORGANIZATIONAL COMMITMENT \\ (OC) ON ORGANIZATIONAL CITIZENSHIP BEHAVIOUR (OCB) OF PERMANENT NURSES
}

\author{
Oleh : \\ Nadia Tri Hastuti ${ }^{1}$ \\ Ugung Dwi Ario Wibowo ${ }^{2}$
}

\begin{abstract}
ABSTRAK
Penelitian ini bertujuan untuk mengetahui apakah ada pengaruh quality of work life dan organizational commitment terhadap organizational citizenship behavior pada perawat tetap. Penelitian ini menggunakan metode kuantitatif dengan subjek penelitian sebanyak 50 perawat tetap. Metode pengumpulan data dengan menggunakan skala likert yang terdiri dari skala organizational citizenship behavior, skala quality of work life, dan skala organizational commitment. Skala organizational citizenship behavior memiliki reliabilitas 0,854 , skala quality of work life memiliki reliabilitas 0,933 dan skala organizational commitment memiliki reliabilitas 0,901 . Metode analisis menggunakan analisis regresi linier berganda. Hasil penelitian menunjukkan bahwa variabel quality of work life berpengaruh signifikan terhadap organizational citizenship behavior. Variabel organizational commitment berpengaruh signifikan terhadap organizational citizenship behavior. Sedangkan variabel quality of work life dan organizational commitment secara simultan berpengaruh signifikan terhadap organizational citizenship behavior.
\end{abstract}

Keywords: quality of work life, organizational commitment, organizational citizenship behavior.

\section{ABSTRACT}

This research aims to identify the effects of quality of work-life and organizational commitment on organizational citizenship behaviour of permanent nurses. The research method is quantitative with 50 research subjects consisting of permanent nurses. The data were collected using Likert scale, consisting of organizational citizenship behaviour scale, quality of work-life scale, and organizational commitment scale. The scale of organizational citizenship behaviour has the reliability of 0.854 , the scale of quality of work-life has the reliability of 0.933 , and the scale of organizational commitment has the reliability of 0.901. Multiple linear regression was used as the analysis method. The research result reveals that the variable of quality of work-life significantly affects the variable of organizational citizenship behaviour. Moreover, the variable of organizational commitment also significantly affects the variable of organizational citizenship behaviour. Meanwhile, the variable of quality of work-life and organizational commitment simultaneously have significant effects on the variable of organizational citizenship behaviour.

Keywords: quality of work-life, organizational commitment, organizational citizenship behavior.

\section{PENDAHULUAN}

Perkembangan zaman yang begitu pesat menuntut organisasi maupun anggotanya untuk mengikuti perkembangan khusunya di bidang teknologi. Salah satu organisasi yang harus mengikuti perkembangan tersebut adalah rumah sakit. Ketika rumah sakit mulai mengikuti perkembangan secara tidak langsung perawat sebagai anggota dari organisasi juga dituntut untuk bisa beradaptasi dan bekerja sesuai dengan prosedur yang lebih baru guna menyesuaikan kondisi saat ini.

Kemajuan teknologi di bidang kesehatan berdampak pula pada meningkatnya kualitas pelayanan pada perawat. Perawat menjadi lebih diuntungkan dalam hal ini sebab dengan

\footnotetext{
${ }^{1}$ Nadia Tri Hastuti, Fakultas Psikologi, Universitas Muhammadiyah Purwokerto

${ }^{2}$ Ugung Dwi Ario Wibowo, Fakultas Psikologi, Universitas Muhammadiyah Purwokerto
} 
adanya peralatan kesehatan yang lebih canggih memudahkan dan meringankan kerja perawat sehingga pasien juga dapat ditanggani dengan cepat dan memberikan feedback yang baik pula bagi rumah sakit ketika pasien merasa puas dengan pelayanan yang diberikan.

Perawat menjalankan berbagai peran dan bekerja di departemen yang berbeda. Pada ruang rawat inap membutuhkan perawat yang mempunyai pemahaman dan kecakapan tertentu dalam menjalankan proses merawat pasien, perawat dituntut untuk senantiasa menggunakan kaidah berpikir kritis, melakukan pengorganisasian pelayanan kesehatan, melakukan beragam terapi terkait dengan keadaan pasien dan harus selalu siap untuk memberi pemahaman kepada pasien. Pada perawat rawat inap intensitas bertatap muka dengan pasien bisa kapan saja dilakukan, karena pasien memerlukan kontrol dan pemeriksaan secara teratur, sehingga perawat merupakan satu dari berbagai macam pekerjaan pelayanan kesehatan yang harus ada selama 24 jam penuh (Ariani \& Kristiana, 2017).

Dalam rangka merealisasikan pelayanan terbaik bagi kepuasan para pasien, rumah sakit tidak hanya memotivasi para perawat untuk mengerjakan tugas utamanya saja namun perlu memperhatikan tugas ekstra perannya dalam mewujudkan harapan dan permintaan pasien serta masyarakat untuk memperoleh pelayanan kesehatan yang maksimal. Tugas ekstra peran yang dimaksud adalah perilaku di luar tugas pokok yang dilakukan secara sukarela oleh para tenaga kerja di tempat kerjanya demi kepentingan organisasinya (Sahrah, 2018).

Perilaku diluar tugas pokok perawat dan kualifikasi interpersonal yang ditunjukkan seseorang perawat antara lain, perawat bersedia membantu rekan kerja lain, membuat komentar positif mengenai rumah sakit, menjauhi masalah yang dirasa tidak penting, dan menawarkan diri untuk mengerjakan tugas ekstra. Perilaku ekstra peran ini yang dinamakan organizational citizenship behavior (OCB) karena perilaku yang dilakukan karyawan melebihi tugas utamanya (Robbins \& Judge, 2008).

OCB adalah perilaku alternatif dan gagasan individu, tidak terkait dengan sistem penghargaan resmi dari organisasi namun dapat menaikan efektivitas organisasi. OCB memfokuskan pada perjanjian sosial antara individu dengan organisasi yang biasanya dibandingkan dengan perilaku in-role yang mendasarkan pada kinerja terbatas yang disyaratkan oleh organisasi (Andriani, Djalali, \& Sofiah, 2012).

Menurut Kolade, Oluseye, dan Omotayo (dalam Fitria, Dewi, \& Febriana, 2016) OCB pun dapat meningkatkan efisiensi dalam pelayanan, kepuasan pasien, citra rumah sakit dan kemudian pada akhirnya bermuara terhadap pencapaian kinerja yang diharapkan oleh rumah sakit. Pegawai yang mempunyai OCB akan bekerja makin giat dan memiliki kemauan untuk bekerja melebihi dari apa yang seharusnya dikerjakan.

Dalam mengembangkan perilaku OCB juga dibutuhkan penciptaan quality of work life (QWL) yang baik. Karyawan yang memiliki QWL yang tinggi akan akan mendorong munculnya OCB, karena memiliki kemungkinan yang lebih besar untuk berbicara positif tentang organisasi, kesediaan membantu orang lain dan melakukan pekerjaan hingga melebihi apa yang diharapkan organisasi (Susanti, 2015).

QWL adalah persepsi karyawan ketika mereka menginginkan adanya rasa aman, kepuasan dan kesempatan untuk berkarya dan berkembang layaknya manusia (Cascio, 2003). Cascio (2006) menambahkan bahwa QWL adalah persepsi karyawan mengenai keamanan dalam bekerja, kepuasaan, keseimbangan antara kehidupan kerja serta kemampuan untuk dapat tumbuh dan berkembang sebagai manusia.

QWL juga menjadi isu yang penting bagi organisasi kesehatan. Rumah sakit merupakan bagian dari suatu yang kompleks, padat modal dan padat teknologi, memerlukan biaya yang tinggi untuk memenuhi permintaan meningkatkan kualitas pelayanan kesehatan, maka rumah sakit perlu untuk meningkatkan produktivitasnya serta dapat memunculkan dan meningkatkan kepuasan kerja perawat agar peningkatan pelayanan kesehatan dapat terkendali 
dengan baik. Kualitas pelayanan kerja dipengaruhi oleh QWL yang menjadi bagian berarti pada pelayanan di bidang kesehatan (Brooks \& Clarke, 2010).

Disamping meningkatkan QWL, kinerja yang optimal dapat terbentuk dengan baik karena adanya komitmen yang ditumbuhkan yaitu komitmen dalam organisasi (Syahbanuari \& Abdurrahman, 2019). Organizational Commitment (OC) juga sebagai salah satu faktor motivasi yang paling penting, sebagai akibatnya seseorang menemukan jati dirinya di dalam organisasi, berperan serta dalam kegiatan-kegiatan organisasi, berbaur dengannya dan menikmati keanggotaannya. Mencapai tujuan organisasi tidaklah mungkin tanpa penerimaan internal dan terus menerus, komitmen dan upaya spontan dari karyawan (Alipour \& Kamaee Monfared, 2015).

Tommy \& Julia (dalam Sari 2017) mengatakan bahwa pegawai yang mempunyai komitmen pada organisasinya, yang dipercaya dapat menyumbangkan waktu, energi dan talenta mereka yang lebih besar kepada organisasi, dibandingkan dengan pegawai yang tidak memiliki komitmen. Oleh sebab itu OC mempunyai peranan penting bagi organisasi dalam proses operasional.

Berdasarkan hasil wawancara dengan bagian kepegawaian diperoleh informasi terkait perilaku OCB, perawat bekerja sudah sesuai dengan job description-nya, namun ketika perawat A sedang berjaga di pavilion $X$ dan tidak ada pasien di pavilion tersebut maka ia akan membantu perawat yang sedang berjaga di pavilion lain yang banyak menangani pasien. Sehingga bisa dibilang perawat memiliki kemauan untuk membantu pekerjaan temannya tanpa adanya suruhan atau paksaan dari siapapun. Jika ada perawat yang tidak dapat hadir maka akan dicarikan pengganti. Selanjutnya terkait dengan kehadiran di tempat kerja masih ada beberapa perawat yang datang terlambat sehingga akan menganggu pelayanan pada rumah sakit. Kemudian terkait dengan hubungan dengan rekan kerja atau masalah mengenai pekerjaannya, sejauh ini hubungan perawat dengan rekan kerjanya baik-baik saja.

Terkait dengan QWL diperoleh informasi melalui hasil wawancara bahwa perawat di berikan program pelatihan setiap tahunnya Ketika perawat memiliki hasil kerja yang baik atau berprestasi dalam kerja maka akan memperoleh kenaikan jabatan, seperti perawat pelaksana naik jabatan menjadi penanggung jawab. Perawat juga akan memperoleh reward berupa beasiswa untuk mengikuti pelatihan. Rumah sakit juga memberikan jaminan kesehatan dan program pensiun untuk perawat tetap. Namun masih ada perawat yang merasa belum puas terhadap tunjangan atau jasa medis yang diberikan.

Selanjutnya berkaitan dengan OC perawat tetap diperoleh informasi bahwa perawat tetap sudah memiliki komitmen organisasi yang tinggi karena yang terpilih menjadi perawat tetap memiliki penilaian yang tinggi pada loyalitas. Namun di lain kesempatan ada perawat yang memilih untuk mengundurkan diri dengan alasan menikah, mengikuti suami atau mengurus anak. Ini terjadi pada perawat tetap perempuan, karena sebagian besar perawat tetap adalah perempuan. Selain itu juga ada yang mengundurkan diri karena mengikuti seleksi untuk menjadi PNS dan jika lolos seleksi maka perawat harus meninggalkan pekerjaannya di Rumah Sakit ini.

Berdasarkan penelitian sebelumnya mengenai korelasi antara QWL dan OCB dari peserta yang diteliti, penelitian ini menunjukkan bahwa ada korelasi positif antara total QWL dan OCB berdasarkan conscientiousness, civic virtue dan altruism. Terdapat hubungan yang signifikan secara statistik antara QWL dan OCB dari peserta yang diteliti, ini berarti bahwa ketika QWL menjadi lebih baik di antara peserta penelitian, perawat menghasilkan lebih banyak perilaku OCB (El-Sayed, El-Fattah, \& Mohamed, 2018). Temuan ini mirip dengan yang ditemukan dalam penelitian yang dilakukan oleh Sandhya (dalam El-Sayed, El-Fattah, \& Mohamed, 2018) yang melakukan studi tentang QWL pada OCB menemukan bahwa ada hubungan yang signifikan antara QWL dan OCB berdasarkan altruism dan conscientiousness. Pada penelitian Nasichudin dan Azuhri (dalam Fitria et al., 2016) diketahui bahwa OC 
berpengaruh secara positif dan signifikan pada OCB. Artinya ketika karyawan memiliki komitmen organisasi dalam menjalankan pekerjaannya, maka mereka memiliki OCB yang baik.

\section{METODE}

Dalam penelitian ini terdapat dua variabel bebas dan satu variabel terikat. Variabel bebas dalam penelitian ini adalah Quality of Work Life (QWL) dan Organizational Commitment (OC) sedangkan variabel terikatnya yaitu Organizational Citizenship Behavior (OCB). Populasi dalam penelitian ini berjumlah 50 perawat tetap, maka penentuan responden dalam penelitian ini adalah menggunakan teknik penelitian populasi.

Metode pengumpulan data yang digunakan dalam penelitian ini adalah metode skala Likert yang terdiri dari skala QWL, skala OC dan skala OCB. Uji validitas dalm penelitian ini menggunakan korelasi product moment pada tingkat kepercayaan 95\% atau $(\alpha=0,05)$. Skala QWL memiliki koefisien validitas bergerak dari 0,309 sampai 0,682, skala OC memiliki koefisien validitas bergerak dari 0,299 sampai 0,710 dan skala OCB memiliki koefisien validitas bergerak dari 0,285 sampai 0,701 . Sedangkan pengujian reliabilitas skala menggunakan rumus Alpha Cronbach. Diperoleh hasil perhitungan uji reliabilitas skala OCB sebesar 0,854, skala QWL sebesar 0,933 dan skala OC sebesar 0,901. Teknik analisis data yang digunakan adalah analisis regresi linier berganda menggunakan SPSS for windows release versi 20.0 .

\section{HASIL}

Hasil uji normalitas menunjukkan bahwa tiga variabel tersebut memiliki sebaran yang normal. Sebaran skor tersebut dapat dilihat dari hasil uji normalitas yang menunjukkan $p$ sebesar 0,653 untuk variabel OCB, p sebesar 0,294 untuk variabel QWL dan p sebesar 0,155 untuk variabel OC.

Berdasarkan hasil uji linieritas antara variabel QWL dan OCB diperoleh $\mathrm{p}=0,177$ dan $F=1,518$, hal ini menunjukkan data tersebut linear karena $p>0,05(0,177>0,05)$. Selanjutnya hasil uji linieritas antara variabel OC dan OCB diperoleh $\mathrm{p}=0,485$ dan $\mathrm{F}=1,014$, hal ini menunjukkan data tersebut linear karena $p>0,05(0,485>0,05)$.

Berdasarkan hasil analisis regresi linier berganda antara variabel QWL dan OCB maka diketahui bahwa $F_{\text {hitung }}=383,511$ dan diperoleh nilai probabilitas sig $(\mathrm{p})=0,000$ karena nilai $\mathrm{p}$ $<0,01$, maka dapat disimpulkan bahwa H1 diterima artinya QWL berpengaruh signifikan terhadap OCB dan $\mathrm{R}_{\text {square }}$ sebesar 0,889 , sehingga $\mathrm{QWL}$ memberikan sumbangan efektif sebesar $88,9 \%$.

Tabel 1.

Koefisien Garis Regresi Quality Work Life

\begin{tabular}{llcccc}
\hline Model & \multicolumn{2}{c}{$\begin{array}{c}\text { Unstandardized } \\
\text { Coefficients } \\
\text { Std. } \\
\text { B }\end{array}$} & $\begin{array}{l}\text { Standardized } \\
\text { Coefficients } \\
\text { Beta }\end{array}$ & T & Sig. \\
\hline Constant $)$ & 1.452 & 4.941 & & & \\
$\mathrm{X} 1$ & .604 & .031 & .943 & 19.583 & .000 \\
\hline
\end{tabular}

Hasil analisis regresi linier berganda antara variabel OC dan OCB maka diketahui bahwa $F_{\text {hitung }}=76,171$ dan diperoleh nilai probabilitas sig $(p)=0,000$ karena nilai $p<0,01$, maka dapat disimpulkan bahwa $\mathrm{H} 2$ diterima artinya $\mathrm{OC}$ berpengaruh signifikan terhadap OCB dan $\mathrm{R}_{\text {square }}$ sebesar 0,613, sehingga OC memberikan sumbangan efektif sebesar $61,3 \%$. 


\section{Tabel 2.}

Koefisien Garis Regresi Organizational Commitment

\begin{tabular}{|c|c|c|c|c|c|}
\hline \multirow[t]{2}{*}{ Model } & \multicolumn{2}{|c|}{$\begin{array}{c}\text { Unstandardized } \\
\text { Coefficients }\end{array}$} & $\begin{array}{c}\text { Standardized } \\
\text { Coefficients }\end{array}$ & $\mathrm{T}$ & Sig. \\
\hline & B & $\begin{array}{l}\text { Std. } \\
\text { Error }\end{array}$ & Beta & & \\
\hline (Constant) & 20.964 & 8.844 & & 2.370 & .022 \\
\hline $\mathrm{X} 2$ & .740 & .085 & .783 & 8.728 & .000 \\
\hline
\end{tabular}

Hasil analisis regresi linier berganda antara variabel QWL dan OC terhadap OCB maka diketahui bahwa $F_{\text {hitung }}=797,346$ dan diperoleh nilai probabilitas sig $(\mathrm{p})=0,000$ karena nilai $\mathrm{p}$ $<0,01$, maka dapat disimpulkan bahwa H3 diterima artinya QWL dan OC secara simultan berpengaruh signifikan terhadap OCB dan $R_{\text {square }}$ sebesar 0,971, sehingga $\mathrm{QWL}$ dan OC memberikan sumbangan efektif sebesar $97,1 \%$.

Tabel 3.

Koefisien Garis Regresi Linier Berganda

\begin{tabular}{lrrrrr}
\hline Model & \multicolumn{2}{c}{ Unstandardized } & Standardized & T & Sig. \\
& Coefficients & Coefficients & & \\
& B & Std. & Beta & & \\
\hline (Constant) & 3.353 & 2.539 & & 1.321 & .193 \\
X1 & 1.098 & .045 & 1.715 & 24.241 & .000 \\
X2 & -.778 & .067 & -.824 & -11.645 & .000 \\
\hline
\end{tabular}

\section{PEMBAHASAN}

Hasil penelitian ini menunjukkan adanya pengaruh yang signifikan antara variabel quality of work life (QWL) dengan organizational citizenship behavior (OCB). Hal ini berdasarkan hasil uji hipotesis dan diperoleh $\mathrm{F}_{\text {hitung }}=383,511$ dengan nilai probabilitas sig $(\mathrm{p})$ $=0,000$ karena nilai $\mathrm{p}<0,01$ maka hipotesis pertama diterima yaitu ada pengaruh $\mathrm{QWL}$ terhadap OCB. Selain itu diperoleh $\mathrm{R}_{\text {square }}$ sebesar 0,889, sehingga QWL memberikan sumbangan efektif sebesar $88,9 \%$ terhadap OCB.

Hasil penelitian ini sejalan dengan hasil penelitian Mohammad, Kiumarsi, \& Hashemi (2016) yang membuktikan bahwa QWL berpengaruh terhadap OCB. Hasil penelitian dari peneliti lain mengungkapkan, QWL berpengaruh signifikan terhadap variabel OCB. Berpengaruh tersebut mempunyai makna apabila semakin baik QWL dalam sebuah organisasi maka akan semakin meningkat pula OCB pada pegawai tersebut (Sumiati, Ardiana, \& Pratiwi, 2018).

Hasil Penelitian yang dilakukan oleh Kurniawati (2018) menyatakan bahwa karyawan yang memiliki QWL yang tinggi akan mendorong timbulnya tindakan-tindakan yang dilakukan karyawan melampaui ketentuan minimum yang diharapkan oleh peran organisasi dan mempromosikan kesejahteraan rekan kerja, kelompok kerja, dan perusahaan.

Hasil penelitian ini menunjukkan adanya pengaruh yang signifikan antara variabel organizational commitment (OC) dengan organizational citizenship behavior (OCB). Hal ini berdasarkan hasil uji hipotesis dan diperoleh $F_{\text {hitung }}=76,171$ dengan nilai probabilitas sig $(\mathrm{p})=$ 0,000 karena nilai $\mathrm{p}<0,01$ maka hipotesis kedua diterima yaitu ada pengaruh $\mathrm{OC}$ terhadap OCB. Selain itu diperoleh $R_{\text {square }}$ sebesar 0,613 , sehingga OC memberikan sumbangan efektif sebesar $61,3 \%$ terhadap OCB.

Hasil penelitian ini sejalan dengan hasil penelitian Sumiati, Ardiana, \& Pratiwi (2018) bahwa variabel OC berpengaruh signifikan terhadap variabel OCB. Dari peneliti sebelumnya oleh Wibowo (2016), berdasarkan hasil pengukuran inner model, diketahui koefisien jalur $\beta 21$ sebesar 0,431 dengan nilai R-square sebesar 0,18, hal ini mengindikasikan secara parsial, hasil 
analisis jalur menunjukkan pengaruh langsung OC pada organisasi syariah terhadap OCB yaitu sebesar 18,6\% mendekati kriteria moderat, dengan hasil t hitung $(8,438)>t$ tabel $(1,960)$, sehingga $\mathrm{H} 0$ ditolak, dalam artianya OC syariah terbukti berpengaruh signifikan terhadap OCB meskipun pengaruh yang diberikan tergolong lemah.

Hasil penelitian dari peneliti lain, OC mempunyai pengaruh yang signifikan terhadap munculnya OCB. OC sebagai bentuk keyakinan pegawai untuk tetap bertahan, melaksanakan kewajiban, terlebih mereka yang memiliki kesamaan dalam nilai-nilai yang diyakini organisasi akan membuat pegawai bekerja dengan sepenuh hati bahkan melebihi tuntutan deskripsi pekerjaan yang merupakan bentuk organizational citizenship behavior (Jaya, 2018).

Penelitian yang dilakukan oleh Dewanggana, Paramita, \& Haryono (2016), OC berpengaruh positif dan signifikan terhadap OCB, semakin kuat komitmen organisasi karyawan maka semakin baik perilaku OCB.

Hasil penelitian ini menunjukkan adanya pengaruh yang signifikan antara QWL dengan OCB. Hal ini berdasarkan hasil uji hipotesis dan diperoleh $F_{\text {hitung }}=797,346$ dengan nilai probabilitas sig $(\mathrm{p})=0,000$ karena nilai $\mathrm{p}<0,01$ maka hipotesis ketiga diterima yaitu $\mathrm{QWL}$ dan OC secara simultan berpengaruh signifikan terhadap OCB.

Penelitian ini sejalan dengan penelitian yang dilakukan oleh Syahbanuari \& Abdurrahman (2019) menunjukkan bahwa QWL dan OC secara simultan berpengaruh terhadap OCB.Penelitian dari peneliti lain, menunjukkan hasil yang signifikan antara variabel QWL dan OCB, artinya semakin tinggi QWL yang dirasakan oleh perawat akan meningkatkan perilaku OCB mereka saat bekerja (Susilawati \& Prestiana, 2017).

Penelitian oleh Susanti (2015) bahwa karyawan yang memiliki QWL yang tinggi akan mendorong timbulnya OCB, karena memiliki kemungkinan yang lebih besar untuk berbicara positif tentang organisasi, kesediaan membantu individu lain, dan melakukan kinerja yang melebihi perkiraan normal.

Penelitian oleh Kashani (2012) menjelaskan bahwa sebuah QWL yang tinggi adalah penting bagi semua organisasi untuk terus menarik dan mempertahankan karyawan, kualitas kehidupan kerja adalah program yang komprehensif yang ditunjukkan untuk meningkatkan kepuasan karyawan dan perilaku kewargaan organisasi.

Hasil penellitian lain juga menunjukkan bahwa OC berpengaruh signifikan terhadap OCB karyawan (Bodroastuti \& Ruliaji, 2016). Sesuai dengan teori yang dikemukakan oleh Luthans (2006), bahwa OC merupakan sikap yang merefleksikan loyalitas karyawan pada organisasi dan proses berkelanjutan dimana anggota organisasi mengekspresikan perhatiannya terhadap organisasi dan keberhasilan serta kemajuan yang berkelanjutan.

Didukung penelitian lain bahwa OC menjadi variabel mediator/interverning pada anteseden OCB dengan kontribusi 69,9\% dibanding variabel lainnya yaitu persepsi terhadap lingkungan dan regulasi diri dalam bekerja (Wibowo, Iskandar, \& Prathama, 2014).

Selanjutnya penelitian yang dilakukan oleh Subejo et al., (2013) yang menunjukkan adanya pengaruh yang signifikan antara OC dengan OCB. Diungkapkan bahwa dampak terpenting munculnya komitmen dalam diri karyawan adalah perilaku positif diluar tugas formal karyawan, yang disebut OCB.

\section{KESIMPULAN}

Berdasarkan hasil penelitian dapat disimpulkan bahwa quality of work life berpengaruh signifikan terhadap organizational citizenship behavior, organizational commitment berpengaruh signifikan terhadap organizational citizenship behavior, serta quality of work life dan organizational commitment secara simultan berpengaruh signifikan terhadap organizational citizenship behavior. 


\section{KEPUSTAKAAN}

Andriani, G., Djalali, M. A., \& Sofiah, D. (2012). Organizational Citizenship Behavior dan Kepuasan Kerja Pada Karyawan. Jurnal Psikologi, 3(01).

Alipour, F., \& Kamaee Monfared, M. (2015). Examining the Relationship between Job Stress and Organizational Commitment among Nurses of Hospitals. Patient Saf Qual Improv, $3(4), 277-280$.

Ariani, M., \& Kristiana, I. (2017). Hubungan Antara Regulasi Emosi Dengan Organizational Citizenship Behavior Pada Perawat Rsud $\mathrm{Hj}$. Anna Lasmanah Banjarnegara. Empati, 6(1), 270-275.

Bodroasuti, T., \& Ruliaji, A. (2016). Pengaruh Komitmen Organisasi Dan Kepuasan Kerja Terhadap Organizational Citizenship Behavior (OCB) Serta Dampaknya Terhadap Kinerja Karyawan. Jurnal Dinamika Ekonomi Bisnis, 13(1).

Brooks, B., \& Clarke, P. (2010). Quality of Nursing Worklife. Nursing Science Quartely, 23(4), 301-305.

Cascio, W. F. (2003). Managing Human Resources. Colorado: McGraw-Hill.

Cascio, W. F. (2006). Managing Human Resources. Colorado: McGraw-Hill.

Dewangga, B. D., Paramita, P. D., \& Haryono, A. T. (2016). Pengaruh Komitmen Organisasi, Kepuasan Kerja, Budaya Organisasi Terhadap Organizational Citizenship Behavior (OCB) Yang Berdampak Pada Prestasi Kerja Karyawan (Studi pada PT. PLN APP Semarang). Journal Of Management, 2(2).

El-Sayed, H. A. E. M., El-Fattah, M. A. E.A., \& Mohamed, W. M. (2018).The Relationship between Quality of Work Life and Organizational Citizenship Behavior among Nurses at El-Mansoura Health Insurance Hospital. Zagazig Nursing Journal, 14(1), 148-157.

Fitria, R. M., Dewi, R. S., \& Febriana, S. K. T. (2016). Peranan Komitmen Organisasi Terhadap Organizational Citizenship Behavior Pada Perawat. Jurnal Ecopsy, 2(1), 8-12. https://doi.org/10.20527/ecopsy.v2i1.510

Jaya, R. (2017). Pengaruh Komitmen Organisasi Terhadap Organizational Citizenship Behavior (OCB) Pegawai Pada BPTPM Kota Pekanbaru. Jurnal EL-RIYASAH, 8(1), 1019.

Kashani, F. H. (2012). A Review on Relationship between Quality of Work Life and Organizational Citizenship Behavior (Case Study; Iranian Company). Journal of Basic and Applied Scientific Research, 2(9), 9523-9531.

Kurniawati, C. E. (2018). Pengaruh Quality of Work Life Terhadap Engagement Dan Organizational Citizenship Behavior Pada Perusahaan Elektronik Di Surabaya. AGORA, 6(2), 1-6.

Luthans, F. (2006). Perilaku Organisasi (Edisi Sepu). Yogyakarta: Penerbit Andi.

Mohammad, S., Kiumarsi, S., \& Hashemi, S. M. (2016). Quality of work life and organizational citizenship behavior among the employees in private universities in Malaysia. International Journal of Business and Innovation, 2(6), 55-56.

Robbins, S. P., \& Judge, A. T. (2008). Perilaku Organisasi: Organizational Behavior. Jakarta: Salemba Empat.

Sahrah, A. (2018). Perceived Organizational Support Dan Organizational Citizenship Behavior Pada Perawat Rumah Sakit. Insight: Jurnal Ilmiah Psikologi, 19(1), 40-56. https://doi.org/10.26486/psikologi.v19i1.598

Sari, R. M. (2017). Pengaruh Iklim Organisasi dan Kepuasan Kerja Terhadap Komitmen Organisasi (Studi Pada Perawat RSIA Eria Bunda Pekanbaru). JOM FISIP, 4(2), 1-10.

Subejo et al. (2013). The Effect of Organizational Commitment and Organizational Identity Strength to Citizenship Behavior (OCB) Impact On Fire Department and Disaster 
Employee Performance in Jakarta Indonesia. Journal of Business and Management, 10(3).

Sumiati, Ardiana, I. D. K. R., \& Pratiwi, A. I. (2018). Pengaruh Komitmen Organisasi, Quality of Work Life (QWL) terhadap Organizational Citizen Behavior (OCB) dan Kinerja Pegawai Pada Dinas Kependudukan dan Pencatatan Sipil Kabupaten Bangkalan Madura Jawa Timur. Jurnal Ilmu Ekonomi \& Manajemen, 05(01), 24-36.

Susanti, R. (2015). Hubungan Religiusitas dan Kualitas Kehidupan Kerja dengan Organizational Citizenship Behavior (OCB) Pada Karyawan. Jurnal Psikologi, 11(2), 94-102.

Susilawati, S., \& Prestiana. (2017). Keadilan Organisasi Dan Kualitas Kehidupan Kerja Terhadap Organizational Citizenship Behavior Pada Perawat Rawat Inap. Soul, 9(2), 8393.

Syahbanuari, B. A., Abdurrahman, D. (2019). Pengaruh Quality OF Work Life (QWL) dan Komitmen Organisasi terhadap Organiational Citizenhip Behavior (OCB) (Studi pada Pegawai Tetap PT Pindad PERSERO Bandung). Prosiding Manajemen, 5(1).

Wibowo, U. A. D. (2016). Kajian Anteseden Komitmen pada Organisasi Syariah dan Pengaruhnya terhadap Perilaku Kewargaan Organisasional Pada Perbankan Syariah di bawah Otoritas Jasa Keuangan Kantor Regional 4 (Jawa Tengah). Disertasi. Program Doktoral Psikologi Universitas Padjajaran.

Wibowo, U. D. A., Iskandar, T. Z., \& Prathama, A. G. (2014). Organizational Commitment as Mediator of Antecendents of Organizational Citizenship Behavior in Sharia Organization. Proceeding of International Conference on Economics, Education and Humanities. 266-270. 